\title{
Risk Assessment on Stroke by Using Framingham Score and the Correlation with Obesity and Profelipid on Bima Ethnic Group at Bima
}

\author{
Hj. Nurwahidah ${ }^{1}$ \\ ${ }^{1}$ Nursing Departement, Poltekkes Kemenkes Mataram, Indonesia \\ Correspondence: Hj. Nurwahidah, S.Kep., Ns. M.Pd, Poltekkes Kemenkes Mataram, Indonesia.
}

Received: May 3, 2019

Accepted: May 19, 2019

Online Published: May 22, 2019

doi:10.20849/ijsn.v4i2.581

URL: https://doi.org/10.20849/ijsn.v4i2.581

\begin{abstract}
Stroke is an acute nerve function disorder which caused by the dysfunctional blood flow to the brain, the symptoms depend on the brain focal area that has dysfunctions. Stroke has become the fifth of the cause of death in the United States, kills nearly 130,000 people each year, 1 of 20 deaths is caused by stroke. In every 40 seconds in the United States, a person is afflicted by stroke. In every 4 minutes, two people died of stroke. Every year approximately 795,000 people in the United States have stroke. Among its 610,000 had stroke for the first time while the rest 185,000 people had their series of occurrence. Research design used in this research is cross sectional method that stresses on certain time data measurement. This research's subject is patients of Health Clinic Center throughout Bima who participate in POLANIS program. The sampling method of this research is consecutive sampling, so the sampling choices are all individuals which comply to the sample criteria, until the designated sample number is reached. Framingham Score Sheet is used by the writer as the research instrument.The correlation test resulted in $\mathrm{p}$ value $>0.05$ so it can be concluded there is no relationship between obesity by framingham score to incidents of stroke and also the correlation test resulted in $p$ value $>0.05$ and it can be concluded that there is no relationship between obesity by framingham score with the risk of stroke. There is no relevance between obesity and cholesterol by framingham score with the incidents of stroke and the risk of stroke for responders in Health Clinic Center throughout Bima.
\end{abstract}

Keywords: Stroke, obesity, cholesterol dan framingham

\section{Introduction}

Stroke is an acute nerve function disorder which caused by the dysfunctional blood flow to the brain, the symptoms depend on the brain focal area that have dysfunctions (WHO, 2011). Stroke has become the fifth in the United States' cause of death, killed almost 130,000 people each year, with the cause of death of 1 person from 20 people is stroke. Every 40 seconds a person is afflicted by stroke in the United States. Every 4 minutes 2 people died of stroke. Every year approximately 795,000 people have stroke in the United States. With 610,000 people have stroke for the first time while 185,000 was having their second or more episodes of stroke (National Center for Chronic Disease Prevention and Health Promotion, 2016).

According to the 2015 American Heart Association National Center, 29.8\% people who have stroke in the year of 2009 to 2012 were the aged 80 years old and more, which showed the biggest percentage in the age group of stroke. While if categorized based on the gender, the $24 \%$ of the people who had stroke was men and the $23 \%$ of them was women (Mozaffarian, et al., 2015). The stroke prevalence based on RISKESDAS 2013 was 12.1\%, was $0.3 \%$ for the cardiac arrest, and $1.5 \%$ for coronary heart disease. This showed that the stroke prevalence was the highest among other harmful non-infectious diseases. The stroke prevalence is bigger as the age increase, that is $43.1 \%$ and $67 \%$ for $\geq 75$ years old for men and women (Health Ministry of Indonesia, 2013).

The risk factors of stroke are many. Several biological factors are age and gender, high blood pressure, cholesterol serum, fibrinogen, while the activity factors are smoking, diet, alcohol consumptions, lack of physical activities, non-hemorrhagic heart diseases, atrial fibrillation, glucose intolerant, in addition there are social characteristics such as education, social class, ethnic, while the environmental factors are temperature, geographical location, and psychology that influence it (Truelsen, et al., 2016). 
In the 1930s, cardiovascular diseases were the cause in half of all death in the United States. That was the reason for Framingham Risk Score measurement (Kannel, 2016).

Several countries or country groups had been applying the measurement to their citizen, but inconsistency of measurement method was found in the Framingham Risk Score between their population with risks and events in each countries. The Framingham Risk Score model is considered accurate in the United States, Australia and New Zealand but not accurate for the Europe and Asia population (Eichler, et al., 2017).

On the other hand, based on the research conducted in Malaysia to 14,863 responders aged 40-65 years old aimed for comparing Framingham Risk Score, Systematic Coronary Risk Evaluation (SCORE) and World Health Organization (WHO)/International Society of Hypertension (ISH) as measurement tools for cardiovascular diseases of Asian population, Framingham Risk Score and SCORE is applicable for Malaysian practitioners. Even though the method of use of the both tools are different. SCORE is more recommended for male. The Framingham Risk Score measurement is conducted by using online calculator which has many indicators (Selvarajah, et al., 2014).

The Framingham Risk Score measurement can predict strokes based on the risk factors calculation that includes age, systolic blood pressure, antihypertension medication, diabetes, smoking status, cardiovascular disease history, atrial fibrillation, and left hypertrophy ventricle (Donald, et al., 2010).

The output of Framingham Risk Score measurement can be used to predict coronary heart disease, myocardia infarct, coronary insufficiency, angina, non-hemorrhagic stroke, hemorrhagic stroke, transient ischemic attack, periphery artery disease, and cardiac arrest for the next 10 years. The use of the Framingham score is more recommended for the age $<85$ years old (Sabayan, et al., 2013).

\section{Method}

Design model of this research is cross sectional that is an approach which stresses on certain time data measurement. The population of this research is patients who are participants of POLANIS activity at Health Clinic Center throughout Bima. The sampling method of this research is consecutive sampling, so the sampling choices are all individuals which comply to the sample criteria, until the designated sample number is reached.

\subsection{Research Procedures}

a. Before doing the measurement with framingham score, the writer reviewed the parameters of age, gender, and smoking habit and measured samples' blood pressure, cholesterol, DM, height, weight, and abdominal/waist measurement

b. Measurements was conducted in every puskesmas visited by the writer and enumerator.

c. The measurements were valued on points based on Framingham Risk Score 10 Years application and categorized to: very low risk if the total score is less than 10 , low risk if the score is between 10 to 15 , medium risk if the score is between 15 to 20, and high risk if the score is more than 20 .

Ethical approval was obtained from the hospital research ethics committees with serial number of approval was obtained at the present time. Writing Informed Consent was obtained from all responders after they got an explanation. The purpose of research and the right to resign of the research described. All responders recorded as anonymous and confidential.

\section{Results}

The result of univariate analysis with responders' characteristics such as: age, gender, educational background, and job. Of all the 81 responders from Health Service Center throughout Bima the modus of age group is elderly with a range of age from 56 to 65 years old that is 34 people $(42.2 \%)$. The modus of gender of responders is female (72.8\%) meanwhile the male responders are 22 people $(27,2 \%)$. This shows that female patients are more likely to have stroke. The educational backgrounds of the responders are 25 people graduated from high school (30.9\%), meanwhile the fewest is 5 people graduated from D3 (19.8\%).

\subsection{Data of the Relationship Between Obesity and Framingham Score}

In this part, the writer will describe the research result of the relationship between Obesity and Cholesterol with Framingham score and the risk of stroke in PKM throughout Bima.

The table below shows the relationship between obesity with the Framingham score and events of Strokes. 


\begin{tabular}{lll}
\hline & Df & P \\
\hline Chi-Square & 104 & 0.465 \\
\hline
\end{tabular}

The table above shows that there is no relevance between obesity with Framingham score and the events of stroke. The correlation test by using Chi-Square shows $\mathrm{P}$ value $=0.465$ which concludes the absent of relevance between obesity with Framingham score and the events of stroke.

\subsection{The Relevance Between Cholesterol and Framingham Score}

The table below shows the relationship between Cholesterol with Framingham score to the events of Stroke.

\begin{tabular}{lll}
\hline & Df & P \\
\hline Chi-Square & 116 & 0.748 \\
\hline
\end{tabular}

The table above shows that there is no relevance between Cholesterol with Framingham score to the events of stroke. The correlation test by using Chi-Square shows $\mathrm{P}$ value $=0.748$ which concludes that there is no relevance between cholesterol with Framingham score to the events of stroke.

\section{Discussion}

\subsection{The Responders' Age Distribution}

The age groups of evaluation on responders' stroke characteristics, based on Ministry of Health of Republic of Indonesia 2009, are adult 36-45 years old, elderly 46-55 years old, more advance elderly 56-65 years old, and even more advance elderly $>65$ years old.

Based on the research conducted at center health service throughout Bima, the responders who have risk of stroke are 4 adults (4.9\%), 25 elderlies (30.8\%), 34 advance elderlies (42.2\%), and 18 even more advance elderlies $(22.1 \%)$. Based on the research the age group that has more risk of stroke is more advance elderly of 56-65 years old of $42.2 \%$. The result is in accordance with what Ariesta et al (2012) stated in their research, that is stroke strikes the most to people aged range from 55 to 64 years old, most of which caused by hypertension.

Ariesta et al (2012) stated in their research that the increase of people who afflicted by stroke is most likely have to do with the increase of the events of stroke risk factors. The stroke risk factors are diabetes mellitus, mental health disorders, habit of smoking, and hypertension where hypertension is an illness that the most common to be found in stroke patients, and does not healed after the first strike of stroke, and it is most commonly happened to patients over 55 year old (Brian-Fred M, Fitzsimmons 2017).

That statement is sponsored by Glen et al (2015) in their research that stated the people who often by stroke are the patients aged 51 to 65 years old and those who have already been stroked by stroke before while that age range is when hypertension is commonly the main reason of non-hemorrhagic stroke, both because of the increase of systolic pressure and diastolic pressure. The higher one's blood pressure, the higher also one's risk on getting stroke especially when one's systolic blood pressure is at the range of $140 \mathrm{mmHg}$ to $160 \mathrm{mmHg}$ or when one's diastolic blood pressure is at the range of $90 \mathrm{mmHg}$ to $100 \mathrm{mmHg}$ is $65.4 \%$.

\subsection{The Responders' Gender Distribution}

This research has more female responders $(72.8 \%)$ than male responders $(27.2 \%)$. Based on the research conducted by Ceylan et al in the year of 2014, the demography of female stroke patients is higher in number than the male patients, that is $58.8 \%$ female and $41.2 \%$ male. The mutual result also found in the research by Saccon et al which shows more female non-hemorrhagic stroke patients than the male. The research conducted by Sawalha also found that non-hemorrhagic patients are bigger in number for female than male with ratio 1:0.84.

The data published by Riskesdas (2013) showed the prevalence of stroke is similar for women and men. The events of non-hemorrhagic stroke will increase by the increase of age. Framingham reported that the events of stroke increased by 1.66 times on male, and 1.93 times on female in every 10 years of age. On the literature review of the research by Timothy (2004) it is stated that the stroke incidents are more often on male but the prevalence is higher on female because there are more women in the entire population. The incidents of stroke are more often afflict men than women. In most age group, more men suffer stroke than women in certain period of time. But the most deaths caused by stroke happened to women. The intake of birth control pills and pregnancy raise the risk of stroke in women. 


\subsection{The Responders' Educational Background Distribution}

The biggest number of responders of this research is graduated from high school that consists of 25 people. The research conducted by Wardhani and Martini (2014) resulted in most of responders that have high educational background have more knowledge in the risks of stroke. One's educational background can influence one's cognitive functions such as listening, comprehension of information, problem solving, behavior, and lifestyle. The higher the educational background of an elderly, the higher also his cognitive function.(Nobel, Mayo, Hanley, Nadeau, \& Daskalopoulou, 2014)

Arikunto (2011) stated that one's knowledge and education are predisposition factors that can influence one's health status. Low knowledge level on stroke as illness and on post-stroke rehabilitation can hinder one's recovery process.

\subsection{The Responders' Job Distribution}

Based on the job distribution of this research, stroke patients mostly are housewives that are $44.4 \%$ from the total number. Wolff (2006) stated that stress can be caused by role conflict in many situations in life such as the role conflict in marriage and in job. Other than that, there is a factor such as change of lifestyle, especially for those who live in the urban cities, behavior such as consumptions of fast foods which contains high fat level, smoking habit, lack of exercise, and stress. All those factors enhance the chance of housewives to have stroke. (Thomas \& Lip, 2017)

\subsection{The Relationship Between Obesity From Framingham Score to Stroke Risk}

Based on the correlation test the p value $>0.05$ so it can be concluded that there is no relevance between obesity with Framingham score and risk of stroke. A research by Deoke, et.al. (2012) done to a hospital patients in India stated that there is no significant relationship between obesity with stroke $(\mathrm{p}=0.43)$. A research conducted by Onwuchekwa,et.al. (2013) showed a similar result. The research was conducted to villagers in South Nigeria and concluded that there is no relationship between obesity and the incidents of stroke.

A research conducted by Hankey at Rochester, showed a statistic resulted in OR value that was not significant to obesity, that is $1.6(95 \%$ CI: $1.4-1.8)$. People with obesity are in risk of having stroke, but the risk isn't directly related. Obesity is one of stroke's risk factor because it can increase chance of hypertension, heart disorders, and diabetes mellitus. Mackay (2004) stated that obesity is the main factor of coronary heart disease and diabetes mellitus.(Curry et al., 2018)

Meanwhile, the research conducted by Nurfaida, Munawir and Suarnianti (2013) concluded that there is no relationship between obesity with incidents of Non-Hemorrhagic Stroke (NHS) at Level II Pelamonia Makasar Hospital $(\mathrm{p}=0.419, \alpha=0.05)$. They claimed that they research's result is in agreement with the result of research which stated that obesity does not have a positive correlation with the incidents of stroke. Wether or not there is a direct relationship between obesity and stroke has not been clear until now. But obesity is usually linked to eating habit, type $2 \mathrm{DM}$, the increase of cholesterol level and the increase of blood pressure which can trigger atherosclerosis process. Especially to those who have central obesity (stomach obesity) (National Vascular Disease Prevention Alliance, 2012)

\subsection{The Relationship Betweeen Cholestreol From Framingham Score to the Risk of Stroke Incidents}

Based on the correlation analysis the p value $>0.05$ so it can be concluded that there is no relevance between obesity and Framingham score to the risk of stroke incidents. A research conducted by Chirtanto, et,al also shows no relationship between cholesterol and stroke incidents, this statement also sponsored by research result of Framingham Study that said there is no relevance between abnormal cholesterol level with stroke incidents both in men and women. This may be caused by abnormal cholesterol level as one of weak risk factor for the trigger of stroke.

While the research conducted by Linda Soebroto in the relationship between cholesterol level on stroke patients in RSUD Dr.Moewardi stated that hypercholesterolemia is the risk factor of stroke with OR value $=3.701$. The research conducted by Irfan Marta (2004) in the relationship between stroke risk factors in the neurology division of national stroke prevention center at RSUP Bukit Tinggi, resulted in hypercholesterolemia as a stroke risk factor with $\mathrm{OR}$ value $=6.032$.

\section{Conclusion}

There is no relevance between obesity by using framingham score with the risk of stroke for responders in Health Clinic Center throughout Bima and there is no relevance of cholesterol by using framingham score with the risk of stroke for responders in Health Clinic Center throughout Bima. 


\section{References}

American Heart Association. (2015). Understanding Stroke Risk. Diunduh dari URL. Retrieved from http://www.strokeassociation.org/STROKEORG/AboutStroke/Understanding-StrokeRisk_UCM_308539_S ubHomePage.js p\#mainContent/

Black, M. J., \& Hawk, H. J. (2009). Medical surgical nursing: clinical management for positive outcome. Elsevier, Singapura.

Ceylan, A., et al. (2014). Epidemiological Study of The Patients Diagnosed as Ischemic Stroke at the Emergency Departement. The Journal of Academic Emergency Medicine, 13, 10-14.

Curry, S. J., Krist, A. H., Owens, D. K., Barry, M. J., Caughey, A. B., Davidson, K. W., ... Wong, J. B. (2018). Risk assessment for cardiovascular disease with nontraditional risk factors: US preventive services task force recommendation statement. Journal of the American Medical Association, 320(3), 272-280. https://doi.org/10.1001/jama.2018.8359

Jickling, G. C., \& Sharp, F. R. (2015). Biomarket panels In Ischemic Stroke. Stroke, 4(3).

Kannel, D. W. B. (2016). Framingham Stroke Risk Score. Framingham Heart Study, V(6), 77-81.

National Vascular Disease Prevention Alliance. (2012). Guidelines for the Assessment of Absolute Cardiovascular Disease Risk. Melbourne: National Stroke Foundation. Retrieved from strokefoundation.com.au/site/media/AbsoluteCVD_GL_webready.pdf

Nobel, L., Mayo, N. E., Hanley, J., Nadeau, L., \& Daskalopoulou, S. S. (2014). Myrisk_stroke calculator: A personalized stroke risk assessment tool for the general population. Journal of Clinical Neurology, 10(1), 1-9. https://doi.org/10.3988/jen.2014.10.1.1

Nurfaida, M. D. S. (2013). Faktor-faktor yang berhubungan dengan kejadian non haemoragic stroke (NHS) pada rumah sakit TK II Pelamonia Makasar. Library.stikesnh.ac.id, 2(5).

Syahrini. (2012). Faktor-Faktor Risiko Hiperensi Primer di Puskesmas Telogosari Kulon Kota Semarang. Jurnal Kesehatan Masyarakat, 1(2), 315-325.

Thomas, M. R., \& Lip, G. Y. H. (2017). Novel Risk Markers and Risk Assessments for Cardiovascular Disease. Circulation Research, 120(1), 133-149. https://doi.org/10.1161/CIRCRESAHA.116.309955

Wardhani, I. O., \& Martini, S. (2014). Hubungan Karakteristik Pasien Stroke Dan Dukungan Keluarga Dengan Kepatuhan Menjalani Rehabilitasi. Jurnal Berkala Epidemiologi, 3(1), 24-34. Retrieved from padahttp://obstetri-ginekologi.fk.unair.ac.id/index.php/JBE/article/view/1310/106

World Health Organization (WHO). (2011) Non-communicable disease surveillance and prevention in South-East Asia Region. India.

\section{Copyrights}

Copyright for this article is retained by the author(s), with first publication rights granted to the journal.

This is an open-access article distributed under the terms and conditions of the Creative Commons Attribution license (http://creativecommons.org/licenses/by/4.0/). 